\title{
Integrating Design Thinking into a Packaging Design Course to Improve Students' Creative Self-Efficacy and Flow Experience
}

\author{
Chao-Ming Yang ${ }^{1}$ and Tzu-Fan Hsu ${ }^{2, *}$ \\ 1 Department of Visual Communication Design, Ming Chi University of Technology, 84 Gungjuan Rd., \\ Taishan Dist., New Taipei City 243303, Taiwan; yangcm@mail.mcut.edu.tw \\ 2 Master's Program in Creative Design and Management, National Taipei University of Business, No. 100, \\ Sec. 1, Fulong Rd., Pingzhen Dist., Taoyuan City 324, Taiwan \\ * Correspondence: nightshift1943@gmail.com; Tel.: +886-3-4506333 (ext. 8791)
}

Received: 31 May 2020; Accepted: 21 July 2020; Published: 23 July 2020

\begin{abstract}
Creativity can be evaluated from learners' internal motivation and learning outcomes. Implementation of innovative teaching methods by teachers can increase students' learning motivation. In this study, convenience sampling was employed to select 54 students from a packaging design course; they were randomly grouped into 12 creative teams. Design thinking was integrated into the packaging design course, and its influence on the students' creative self-efficacy and flow experience was investigated through empirical research. A pretest-posttest design was adopted to perform teaching experiments. In the pretest, conventional lectures were employed, whereas in the posttest, design thinking teaching was incorporated into the course. Packaging design practice spanned 4 weeks. The experiment results revealed that in the 12 creative teams, the students' creative self-efficacy and flow experience were superior in the posttest than in the pretest. The results also demonstrated that design thinking improved the self-efficacy of students with low creativity tendency as well as the creative flow experience of all students regardless of creativity tendency.
\end{abstract}

Keywords: packaging design; design thinking; creative self-efficacy; flow experience; sustainability for design education

\section{Introduction}

The emergence of self-service merchandise has rendered packaging design increasingly important [1]. However, the packaging appearance of merchandise involves two- and three-dimensional concepts [2] and must conform to the purchase needs of the target consumers [3]. Consequently, the packaging design of merchandise is an extremely complicated design topic. Reviewing the methods for teaching traditional packaging design indicates that most of such methods involve teachers lecturing on theories and then hands-on practice by students. However, the time gap between the theories and practice often prevents students from comprehending the key points of the course unit. Such bidirectional problems between teaching and learning have long existed in design education [4]. In fact, packaging design has the characteristics of both visual design and product design, and design intent involves the problems of brand visuals, container structures, and usage functions. Packaging design is a design course requiring both creativity and professionality $[5,6]$. Accordingly, the objective of this study was to determine how to subvert the traditional course model of packaging design and improve students' design creativity.

In current methods of teaching packaging design, teachers mostly focus on the internal factors of packaging, namely the visual design aspect. These factors include the techniques of presenting packaging, graphic forms, and visual styles. By contrast, less attention is given to the external factors 
of packaging design, such as the social background, usage method, and purchasing population [7]. In addition, numerous problems have needed solutions concerning the cultivation of Taiwanese packaging design talent in the past decade. These problems include the design of packaging models that lack creativity, insufficient cultivation of packaging designers, and inadequate marketing strategies and manufacturing techniques [4]. Such problems indicate that packaging design courses must be taught using more innovative teaching methods. Therefore, the second objective of this study was to discover how problem-based learning (PBL) [8] can be employed to strengthen students' learning motivation and interest in packaging design courses.

In recent years, design thinking has been deeply valued by scholars and widely employed by businesses to solve commercial and social problems, because design thinking can provide an insight into consumers' minds and needs [9]. Design thinking is a human-centered creative thinking method [10]. The largest difference between design thinking and traditional analytical thinking is that design thinking is a creative thinking method that leans toward emotional analysis. Conversely, analytical thinking is a creative thinking method employing rational analysis [11]. Design thinking can help designers identify the real needs of consumers, and reasonable and artistic creative ideas can be proposed when considering such needs [12]. Accordingly, the third objective of this study was to determine how design thinking can be introduced into a packaging design course to improve students' creative self-efficacy and flow experience.

One crucial strategy in Taiwanese education has long been the improvement of students' creativity through teaching. In response to the needs of the creative economy age, countries worldwide considered the cultivation of student creativity as an education development direction and a means to improve national competitiveness $[13,14]$. Therefore, this teaching study introduced the methodology of design thinking into a packaging design course. The influence of design thinking on design creativity was investigated through empirical teaching research, and students' creative self-efficacy and flow experience were analyzed. The three major objectives of this study were as follows:

1. To analyze the effect of the design thinking teaching method on students' creative self-efficacy regarding packaging design.

2. To analyze the effect of the design thinking teaching method on students' flow experience regarding packaging design.

3. To construct a practical teaching model of the application of the design thinking teaching method in the packaging design course.

\section{Literature Review}

\subsection{Connotation and Teaching of Packaging Design}

The American Packaging Association defined the term "packaging" as "the preparation work implemented for the transportation, circulation, storage, and sale of goods" [4]. Packaging design begins from the type of packaging protection required and extends to the effective dissemination of brand image. This process involves usage function, visual design, and brand marketing problems [6]. The original functions of packaging are to protect and contain merchandise. However, as time has passed, consumers' consciences have become more critical, and the consumer social structure has developed. Apart from the initial function of merchandise protection, packaging is also expected to increase sales [5]. From the commercial perspective, packaging design requires planning for addressing comprehensive packaging problems. The content of packaging design should at least include the choice of packaging methods and materials, the visual design thinking (which is the surface pattern design) [15], and the transmission and added value of brand messages [16]. Thus, packaging is not only a protector of products but also a silent salesperson. This is because merchandise packaging influences consumers' evaluation of products and consumption desire [17].

Merchandise packaging is present in everybody's life. It not only plays the role of a silent salesperson but also adds value to the merchandise [15]. Therefore, packaging influences life, and vice 
versa [18]. Generally, packaging design can be divided into commercial packaging design (or consumer packaging design) and industrial packaging design (or structural packaging design) according to its purpose [19]. Both types of packaging design must have the following five major functions: (1) merchandise protection and storage; (2) merchandise transportation and distribution; (3) merchandise safety and sanitation; (4) brand identification and merchandise information transmission; and (5) use of recyclable and reusable packaging materials [20]. To accommodate the demand for packaging design talent in the 21st century, countries worldwide are reforming the design education system and exploring various potential methods for cultivating packaging designers. The model for cultivating packaging design talent involves the social economy (brand marketing), politics (environmental protection and carbon reduction), and culture (local characteristics) [21]. Therefore, different eras require differing talent cultivation models, and the current era also entails its unique model for fostering design talent.

From the perspective of design education, packaging design is a compulsory subject in most design departments, demonstrating its importance. However, in packaging design courses in Taiwan, teachers mostly emphasize professional theories. This teaching approach inefficiently guides students using dynamic thinking and static teaching to transform design concepts into products. This is because under this approach, the teaching environment is closed-minded and limits teaching methods; teachers must also follow specific teaching norms and orders. Consequently, the entire teaching process suppresses design thinking and is passive and narrow-minded [7]. To address this problem, Yang [4] made several teaching recommendations: (1) A design course should be introduced using real products, and students should practice in groups; (2) students should gain an understanding of packaging concepts on the basis of their acquired knowledge; and (3) students should be guided to improve their design expressiveness and communication ability from the perspective of the industry. To conclude, packaging design courses are valued in Taiwan, but teachers focus overly on theory lectures. Thus, students cannot determine the relationship between merchandise packaging and consumers or identify the real needs of consumers. Consequently, the packaging design courses in Taiwan must be reformed to increase their innovativeness.

\subsection{Application of Design Thinking}

A learning trend for design thinking has recently spread throughout the industry and academia. T. Brown, the president of the IDEO design company, defined design thinking as a human-centered approach that considers people's needs and behaviors as well as the feasibility of technology or commerce [22]. The design thinking model well known today was originated from Stanford University in the 1980s. Since then, the Hasso-Plattner Institute of Design at Stanford (i.e., the d. school) has used design thinking methodology to train students to first consider the perspective of human needs. Thus, the real problems between products, services, and consumers can be solved. The innovative solutions that conform to users' needs can be developed from all walks of life and be unpredictable [23].

To respond to the trend of social complication and meet consumer needs, the methodology of design thinking has been deeply valued by scholars. Additionally, it has been widely applied by enterprises and organizations to solve commercial and social problems [9]. In the past 10 years, increasing numbers of scholars have advocated design thinking because this methodology can provide innovative methods of problem solving in greatly complex society and environments [23]. Design thinking is suitable for training interdisciplinary teams. Design teams start from the dimension of emotional analysis and emphasize the relationships between topics and users. Specifically, they start from understanding problems, and then proceed to the steps of problem inspiration, ideation, and implementation [24]. Currently, most teachers simplify the conception process within design thinking into five major steps: empathy, definition, ideation, prototyping, and testing [25] (Figure 1). 


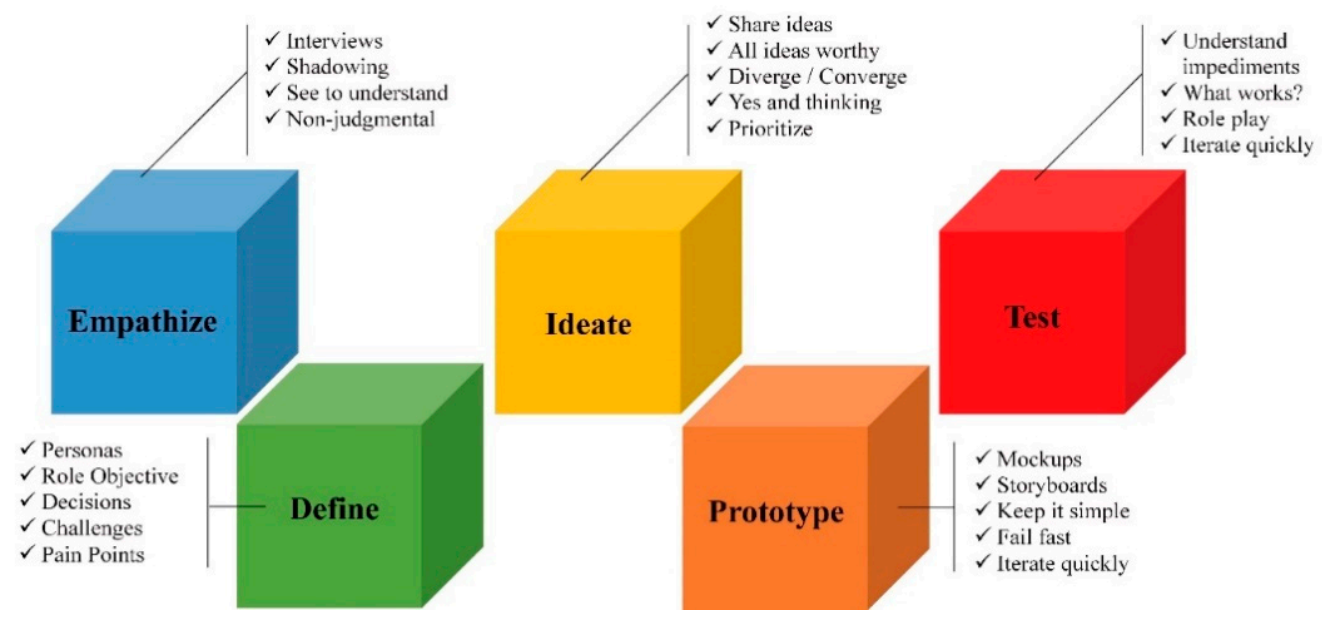

Figure 1. Five major steps of design thinking of Stanford University.

In various fields, the production and accumulation of knowledge originate from activities. Design thinking is an activity in which strategies and methods are proposed through group brainstorming for solving problems [11]. Johansson-Sköldberg et al. [24] stated that the design thinking methodology accounts for both theories and practice. Teamwork is needed to solve complex problems and create innovative design outcomes. Therefore, teamwork is highly crucial to the design thinking training of students. Dunne and Martin [9] mentioned that design thinking involves combining the ideas of every group member and finally proposing the optimal solution to the problem through teamwork. This method can be used to not only create products but also conduct organization management and address social issues. In training on design thinking, teaching students to discover human needs through observation is essential [26]. Lindberg, Meinel, and Wagner [27] indicated that the training focus of design thinking should be the construction of novel ideas and discovery of solutions for wicked problems. In the process of creative thinking, everyone can propose ideas and several ideas can be combined to form an innovative design proposal. Finally, Tschimmel [28] reported that design thinking is a series of problem-solving processes from discovery, definition, and development to delivery. Group members collectively come to understand the problem, observe populations, brainstorm, and finally manufacture the product prototype. This process enables all members to focus on the same theme and propose an innovative idea that meets consumer needs.

\subsection{Nature and Measurement of Creativity}

The verb to create comes from "creatus" in Latin, which has the meaning of bringing something into being [29]. American psychologist Guilford defined creativity as "the individual ability to create novel, unique, fluid, and refined products," and this is the most widely accepted definition [30]. In addition, the content of creativity involves four critical factors, which are called the four Ps of creativity: person, process, product, and press or environment [31]. Although creativity is considered a basic cognitive ability [32], numerous scholars consider creativity to be one of humanity's most complex behaviors. Measuring creativity using a single index in real life is difficult [33]. Theoretically, the measurement of creativity can be divided into the single approach and confluence approach. The single approach involves discussion of personality traits and the characteristics of thinking or products. The confluence approach involves discussing the expression of creativity and how creativity is generated [34]. Most scholars state that creativity cannot be considered using the single approach, because measured results only have meaning when there exists a confluence of multiple factors [35].

Williams [36] reported that in teaching scenarios, observation of students' cognitive and affective performance has a strong positive influence on their creativity. The cognitive behavior is the students' acquisition of knowledge concepts, principle applications, and problem-solving ability, whereas the affective behavior is the students' affirmative or negative psychological reactions to external 
stimulation [37]. If teachers can adequately use tools to measure cognitive and affective behaviors, they must be able to understand the improvement of students' creativity. Cropley [38] further indicated that creative performance can be evaluated in four dimensions: knowledge, thinking skill, motive, and personality traits. Personality traits are particularly critical because a person's traits and will are the key to determining whether he or she can become a creative person [39]. In addition, in the investment theory for creativity proposed by Sternberg and Lubart [35], personality traits are one of the six main resources required for creativity. In fact, creativity tendencies are the personality tendencies that individuals exhibit during creative activities [40]. This personality tendency includes attitude, motive, interest, and emotion [41].

Regarding the personality traits relevant to creativity, Qian, Plucker, and Shen [42] have considered creativity tendency to have the strongest influence on creativity. Studies have also demonstrated that the creativity tendency has a positive influence on the creativity of students. The creativity tendency scale in the Creative Assessment Packet designed by Williams [37] is the scale most used by scholars to evaluate the personality traits relevant to creativity tendency [42]. In addition, Tierney and Farmer [43] proposed the concept of creative self-efficacy to evaluate the application of self-efficacy in special fields. Linnenbrink and Pintrich [44] reported that the concept of self-efficacy is applicable to specific fields and scenarios; hence, it is strongly predictive when evaluating specific learning activities. Various scholars have discovered that creative self-efficacy has a positive influence on creative performance [45-47]. Mathisen and Bronnick [48] further reported that when students have higher creative self-efficacy, they are more confident in their creative behaviors. They are also more willing to accept challenges and thus be even more creative. Finally, Csikszentmihalyi [49] proposed flow experience to explain the relationship between situational motivation and creativity. He stated that in any creative activity, if the creator can fully focus to the level of neglecting everything else and losing track of time and space, an ultimate playful feeling is created, and creativity is expressed [50]. Thus, the flow experience can be used to express a person's feelings during a creative activity. The stronger the flow, the more fun the person is having, and the more creative the person is likely to be. In summary, the study hypothesizes that in the field of packaging design, team members brainstorm and share their creative ideas without criticism through the power of teamwork. This could help creators to more easily immerse themselves in the creative process, stimulate personal creative self-efficacy, and ultimately exhibit self-creativity.

\section{Materials and Methods}

\subsection{Participants and Procedure}

This study targeted students from the Department of Visual Communication Design at Ming Chi University of Technology. A teacher used convenience sampling to select 54 students (15 male and 33 female) from packaging design courses. After confirming the participants, the teacher randomly assigned the 54 students into 12 groups, with four members in each group. At the beginning of the teaching experiment, the teacher explained the study objectives and teaching methods to all participants. The students could choose to stop participating in the experiment at any time, and all research processes conformed to the norms of academic research ethics. No students chose to leave the experiment. Therefore, the integrity of the collected data was high.

The teaching experiment was conducted using a pretest and posttest. The pretest comprised 4 weeks of teaching, with $3 \mathrm{~h}$ of traditional lectures and discussion conducted every week, and after these 4 weeks, every group presented its packaging design. In addition, the participants completed the Creative Self-Efficacy scale [43] and Flow Experience scale [49]. In the posttest, the teaching time was the same as that in the pretest, but the teaching method was altered to include the teaching activities of design thinking. After the posttest course, the groups again presented their packaging design, and all participants again completed the two scales. Subsequently, the differences in creative self-efficacy and flow experience were identified between the pretest and posttest and between the groups of students with high and low creativity tendencies. 


\subsection{Course Design}

The course in this study was divided into the pretest course and posttest course. These courses had the same mission, which was to design packaging for merchandise. In the final class of each course, the groups had to present their design results. The pretest course was centered on the teacher. In every class, the teacher lectured for $1 \mathrm{~h}$, and then the groups of students discussed and practiced for $2 \mathrm{~h}$. The course emphasized tips given by the teacher regarding packaging design, including packaging materials, product forms, packaging design and business marketing, and the design forms of packaging container structures. The posttest course was centered on the students. Once the teacher had explained the methods and processes of design thinking, the groups brainstormed and thought of creative ideas. The course emphasized the application of design thinking in packaging design. The course content included consumer empathy maps, merchandise packaging demand definitions, and the conception of packaging design ideas. The teacher played only a supporting role in this course. The entire course information and content explanation are presented in the Appendix A.

\subsection{Creativity Tendency Grouping}

This study employed the Williams Creativity Tendency scale [37], which has 50 questions and is scored using a 3-point Likert scale. The participants' scores in four dimensions-adventure, curiosity, imagination, and challenge-were obtained. The scores of the four dimensions were summed to obtain the participants' total score in creativity. This study adopted the total score to analyze creativity tendency in accordance with related studies [51], because creativity involves not only the knowledge dimension but also the emotion and meaning dimensions. Personality traits are part of emotion, whereas personality tendency is associated with meaning [39]. Specifically, creativity tendency is a personality trait; it is thus associated with affection. Personal affections should be interpreted from a comprehensive perspective [41]. Prabhu, Sutton, and Sauser [52] reported that it is more suitable to analyze personal traits from a comprehensive perspective. The aforementioned assertions were the main reasons for using the total score from the Creativity Tendency scale to group the participants in this study. The total score of every participant was calculated. Next, the median was used as the cutoff point for grouping, and the students were divided into the high- and low-creativity tendency groups. The effects of creativity scores on creative self-efficacy and flow experience were examined.

After the participants' responses were collected, the internal consistency and reliability of the scale were analyzed. The results revealed that the internal consistency coefficients (Cronbach's $\alpha$ ) of the four dimensions were between 0.801 and 0.853 . The internal consistency coefficient of the creativity tendency total score was 0.841 . The internal consistency reliability was thus favorable $(\alpha>0.7)$ [53]. Next, the median of the scale total score (118.5) was employed to group the participants according to creativity tendency. A total of 24 students ( 6 males and 18 females) were in the low-creativity tendency group, with scores between 88 and 116 (mean $M_{\text {low-creativity tendency group }}=108.58$, standard deviation [Std.] = 7.55), and 24 students ( 9 males and 15 females) were in the high-creativity tendency group, with scores between 121 and $133\left(M_{\text {high-creativity tendency group }}=127.54\right.$, Std.$\left.=3.59\right)$. Finally, the independent sample $t$ test was used to verify the differences in creativity tendency between the two groups. The test results revealed that when $t$ was $-11.11(d f=46)$, the difference reached the significance level of $p<0.001(p=0.000)$. Therefore, the two groups were suitable as the independent variables of the teaching experiment (Table 1$)$.

Table 1. Independent sample $t$-test results for creativity tendency grouping.

\begin{tabular}{|c|c|c|c|c|c|c|}
\hline Research Variables & $N$ & $M$ & Std. & $t$ & $d f$ & Sig. \\
\hline Low-creativity tendency group & 24 (6 males, 18 females) & 108.58 & 7.55 & \multirow{2}{*}{-11.11} & \multirow{2}{*}{46} & \multirow{2}{*}{$0.000^{* * *}$} \\
\hline High-creativity tendency group & 24 (9 males, 15 females) & 127.54 & 3.59 & & & \\
\hline
\end{tabular}




\subsection{Creative Self-Efficacy Questionnaire Design}

Creative self-efficacy can be viewed as the level of beliefs that supports an individual to continue when encountering the challenges of creative missions [43]. More specifically, when individuals exhibit higher creative self-efficacy, they are more likely to continue engaging in creative activities. When individuals demonstrate lower self-efficacy, they are more likely to give up on such activities and thus perform poorly in creativity. Studies have demonstrated that creative self-efficacy effectively predicts creative performance [48,54].

This study referenced Hung [55] to modify and organize the Creative Self-Efficacy scale. This scale has three major dimensions: Efficacy of creative thinking (ECT; four items), Efficacy of creative production (ECP; four items), and Persistence of efficacy in the face of negative feedback (PEFNF; four items). The scale was scored using a 5-point Likert scale, as follows: $1=$ strongly disagree, $2=$ disagree, $3=$ unsure, $4=$ agree, and $5=$ strongly agree. The higher the score is, the more the student's situation matches the scenario described in the question. The scores in each dimension of the scale are then calculated.

The participants completed the Creative Self-Efficacy scale after the pretest course and then after the posttest course. After the participants' responses were collected, the internal consistency reliability of the pretest and posttest scale scores were analyzed. The results for the pretest scale revealed that the internal consistency reliability coefficient (Cronbach's $\alpha$ ) was between 0.774 and 0.843 for the three dimensions and 0.817 for the entire scale. In the posttest, the Cronbach's $\alpha$ was between 0.798 and 0.865 for the three dimensions and 0.828 for the entire scale. The findings indicate that the internal consistency reliability of both the pretest and posttest scales was favorable $(\alpha>0.7$; Table 2$)$.

\subsection{Flow Experience Questionnaire Design}

In 1975, Csikszentmihalyi proposed that when people are engaging in an activity, if they fully concentrate on the scenario, they focus solely on the activity and filter out all unrelated perceptions, and they enter the state of flow [56]. The flow experience enables an activity participant (or creator) to become immersed in a collective experience [57]. The consciousness is then extremely focused. The person reacts only to concrete goals and specific feedback and creates a sense of control over the environment. Other unrelated perceptions and thinking are all filtered out.

This study referenced Yoshida et al. [58] and Magyaródi et al. [59] to design the Flow Experience scale. The scale has four dimensions: Mission challenge (MC; four items), Dedication level (DL; four items), Time and space distortion (TSD; four items), and Positive pleasure (PP; four items). The scale was scored using a 5-point Likert scale, as follows: $1=$ strongly disagree, $2=$ disagree, $3=$ unsure, $4=$ agree, and $5=$ strongly agree. The higher the score is, the more the student's situation matches the scenario described in the questionnaire. The scores in each dimension of the scale are then calculated.

The participants completed the Flow Experience scale after the pretest course and then after the posttest course. The internal consistency reliability of the pretest and posttest scales was analyzed, and the pretest scale analysis results revealed that the internal consistency reliability coefficient (Cronbach's $\alpha$ ) was between 0.788 and 0.859 for the four dimensions and 0.841 for the entire scale. For the posttest, the Cronbach's $\alpha$ was between 0.785 and 0.849 for the four dimensions and 0.832 for the entire scale. Therefore, the internal consistency reliability of both tests was favorable $(\alpha>0.7$; Table 3$)$. 
Table 2. Internal consistency reliability analysis for the creative self-efficacy scale.

\begin{tabular}{|c|c|c|c|c|}
\hline \multicolumn{2}{|r|}{ Question Description } & \multirow{2}{*}{ Main Dimension } & \multicolumn{2}{|c|}{ Cronbach's $\alpha$} \\
\hline & & & Pretest & Posttest \\
\hline 2. & $\begin{array}{l}\text { When I face a new design problem, I can quickly think of multiple solutions. } \\
\text { When I encounter a difficult design problem, I can try new methods to solve it. }\end{array}$ & \multirow[t]{3}{*}{$\begin{array}{l}\text { Efficacy of creative thinking } \\
\qquad(\mathrm{ECT})\end{array}$} & \multirow[t]{3}{*}{0.843} & \multirow[t]{3}{*}{0.798} \\
\hline 3. & When I face a challenging mission, I can think of a large amount of related knowledge. & & & \\
\hline 4. & When facing a design theme, I can always think of answers that others cannot. & & & \\
\hline 5. & I can make products that surprise people. & \multirow{4}{*}{$\begin{array}{l}\text { Efficacy of creative production } \\
\qquad(\mathrm{ECP})\end{array}$} & \multirow{4}{*}{0.774} & \multirow{4}{*}{0.811} \\
\hline 6. & Compared with those of others, I think my works are more ingenious. & & & \\
\hline 7. & I can cleverly utilize ordinary materials or ideas to make my designs more creative. & & & \\
\hline 8. & I don't think that my designs are special (negative question). & & & \\
\hline 9. & $\begin{array}{l}\text { Even if the teacher does not encourage my innovative viewpoint, I still think about } \\
\text { different solutions to the problems. }\end{array}$ & \multirow{4}{*}{$\begin{array}{l}\text { Persistence of efficacy in the } \\
\text { face of negative feedback } \\
\text { (PEFNF) }\end{array}$} & \multirow{4}{*}{0.806} & \multirow{4}{*}{0.865} \\
\hline 10. & $\begin{array}{l}\text { Even if the group members do not appreciate my unique viewpoints, I still always use } \\
\text { my imagination. }\end{array}$ & & & \\
\hline 11. & When somebody in the group criticizes my creative ideas, I give up (negative question). & & & \\
\hline 12. & When the teacher does not accept my design concepts, I insist on my ideals. & & & \\
\hline \multicolumn{3}{|c|}{ Overall } & 0.817 & 0.828 \\
\hline
\end{tabular}


Table 3. Internal consistency reliability analysis for the flow experience scale.

\begin{tabular}{|c|c|c|c|c|}
\hline \multirow{2}{*}{\multicolumn{2}{|c|}{ Question Description }} & \multirow{2}{*}{ Main Dimension } & \multicolumn{2}{|c|}{ Cronbach's $\alpha$} \\
\hline & & & Pretest & Posttest \\
\hline 1. & This activity is a test of imagination for me. & \multirow{4}{*}{ Mission challenge (MC) } & \multirow{4}{*}{0.845} & \multirow{4}{*}{0.808} \\
\hline 2. & I find this activity very challenging. & & & \\
\hline 3. & Compared with other course assignments, this activity is more challenging. & & & \\
\hline 4. & During the course activity, I feel a lot of pressure (negative question). & & & \\
\hline 5. & I dedicate myself to creation in the course activity. & \multirow{4}{*}{ Dedication level (DL) } & \multirow{4}{*}{0.796} & \multirow{4}{*}{0.849} \\
\hline 6. & During the course activity, I am extremely focused. & & & \\
\hline 7. & During the course activity, my attention is strong. & & & \\
\hline 8. & During the course activity, I still think a lot about trivial things (negative question). & & & \\
\hline 9. & During the course activity, time seems to pass very quickly. & \multirow{4}{*}{ Time and space distortion (TSD) } & \multirow{4}{*}{0.788} & \multirow{4}{*}{0.785} \\
\hline 10. & During the course activity, I seem to forget about surrounding things. & & & \\
\hline 11. & During the course activity, I seem to lose the sense of time. & & & \\
\hline 12. & During the course activity, I feel that time goes faster than usual. & & & \\
\hline 13. & When my team finished the product, I felt satisfied. & \multirow{4}{*}{ Positive pleasure (PP) } & \multirow{4}{*}{0.859} & \multirow{4}{*}{0.822} \\
\hline 14. & My team finishing the product made me feel happy. & & & \\
\hline 15. & During the course activity, I was always anxious (negative question). & & & \\
\hline 16. & This course activity enabled me to fully express my design creativity. & & & \\
\hline & Overall & & 0.841 & 0.832 \\
\hline
\end{tabular}




\section{Results}

\subsection{Descriptive Statistical Analysis}

A SPSS 22.0 was employed to perform descriptive statistical analysis and related variable tests. Tables 4 and 5 display the mean values and standard deviations of the Creative Self-Efficacy and Flow Experience scale scores of the 12 groups (54 students) when they had been given traditional lecture teaching (pretest) and design thinking teaching (posttest). The three dimensions of creative self-efficacy were beliefs in one's creative product, creative thinking strategies, and contending against negative reviews, whereas the four dimensions of flow experience were mission challenge, dedication level, time and space distortion, and positive pleasure. The creative self-efficacy and flow experience posttest scores were superior to those in the pretest for all 12 groups. A preliminary interpretation of the results indicated that design thinking had positive effects on the students' creative self-efficacy and flow experience. Subsequently, related statistical tests were conducted to determine whether the differences between variables were statistically significant.

\subsection{Creative Self-Efficacy}

Firstly, the study used an independent-sample $t$ test in the posttest for the "gender" factor to verify whether gender affected creative self-efficacy. The test result was $t(1,52)=-0.628, p>0.05(p=0.267)$; therefore, gender did not affect creative self-efficacy. Secondly, this study employed the difference of means test to test the pretest-posttest differences in the creative self-efficacy variables (Table 6 ). For the dimension of ECT, $F(1,94)=7.88$, and $p<0.01\left(p=0.006, \eta^{2}=0.077 ; M_{\text {posttest }}=3.63>M_{\text {pretest }}=3.23\right)$. For the ECP dimension, $F(1,94)=14.03$, and $p<0.001\left(p=0.000, \eta^{2}=1.30 ; M_{\text {posttest }}=3.48>M_{\text {pretest }}=3.06\right)$. For the dimension of PEFNF, $F(1,94)=5.58$, and $p<0.05\left(p=0.020, \eta^{2}=0.056 ; M_{\text {posttest }}=3.58>\right.$ $\left.M_{\text {pretest }}=3.28\right)$. Finally, for the creative self-efficacy total score, $F(1,94)=11.83$, and $p<0.01(p=0.001$, $\eta^{2}=0.112 ; M_{\text {posttest }}=3.54>M_{\text {pretest }}=3.18$ ). These results indicated that integrating design thinking into the packaging design course improved the students' creative self-efficacy.

Table 4. Mean and standard deviation of creative self-efficacy performance.

\begin{tabular}{|c|c|c|c|c|c|c|}
\hline \multirow{4}{*}{ Groups } & \multicolumn{6}{|c|}{ Creative Self-Efficacy } \\
\hline & \multicolumn{2}{|c|}{ ECT } & \multicolumn{2}{|c|}{ ECP } & \multicolumn{2}{|c|}{ PEFNF } \\
\hline & Pretest & Posttest & Pretest & Posttest & Pretest & Posttest \\
\hline & $M(S t d)$. & $M(S t d)$. & $M(S t d)$. & $M(S t d)$. & $M(S t d)$. & $M(S t d)$. \\
\hline 1 & $3.56(0.80)$ & $3.75(1.06)$ & $3.56(0.91)$ & $3.50(0.93)$ & $3.33(0.74)$ & $3.76(0.88)$ \\
\hline 2 & $3.13(0.75)$ & $3.31(0.52)$ & $2.56(0.53)$ & $3.31(0.47)$ & $3.08(0.83)$ & $3.58(0.96)$ \\
\hline 3 & $2.75(1.02)$ & $4.13(1.09)$ & $3.01(0.35)$ & $3.69(0.83)$ & $3.33(0.98)$ & $3.66(0.98)$ \\
\hline 4 & $2.94(0.88)$ & $2.88(0.66)$ & $2.56(1.03)$ & $3.12(0.75)$ & $2.92(0.88)$ & $3.25(0.63)$ \\
\hline 5 & $3.68(0.32)$ & $3.43(0.94)$ & $3.31(0.43)$ & $3.18(0.93)$ & $3.50(0.79)$ & $3.50(0.92)$ \\
\hline 6 & $3.50(0.41)$ & $3.50(0.84)$ & $3.31(0.95)$ & $3.50(0.85)$ & $3.33(0.59)$ & $3.42(0.91)$ \\
\hline 7 & $3.43(0.71)$ & $3.25(0.54)$ & $3.13(0.63)$ & $3.69(0.52)$ & $3.25(0.32)$ & $3.67(0.77)$ \\
\hline 8 & $3.00(0.41)$ & $4.31(0.52)$ & $3.00(0.35)$ & $4.00(0.65)$ & $3.33(0.82)$ & $4.00(0.72)$ \\
\hline 9 & $3.44(1.03)$ & $3.75(0.74)$ & $3.06(0.55)$ & $3.19(0.52)$ & $3.58(0.79)$ & $3.67(0.86)$ \\
\hline 10 & $2.94(0.75)$ & $3.69(0.58)$ & $3.18(0.59)$ & $3.31(0.52)$ & $3.17(0.43)$ & $3.25(0.63)$ \\
\hline 11 & $3.50(0.71)$ & $3.75(0.61)$ & $3.50(0.65)$ & $3.88(0.60)$ & $3.42(0.96)$ & $3.58(0.91)$ \\
\hline 12 & $2.94(0.39)$ & $3.75(0.56)$ & $2.56(0.63)$ & $3.44(0.58)$ & $3.08(0.74)$ & $3.67(0.72)$ \\
\hline Total & $3.23(0.98)$ & $3.63(0.92)$ & $3.06(0.86)$ & $3.48(0.87)$ & $3.28(0.66)$ & $3.58(0.93)$ \\
\hline
\end{tabular}

Note: ECT = Efficacy of creative thinking; ECP = Efficacy of creative production; PEFNF = Persistence of efficacy in the face of negative feedback. 
Table 5. Mean and standard deviation of flow experience performance.

\begin{tabular}{|c|c|c|c|c|c|c|c|c|}
\hline \multirow{4}{*}{ Groups } & \multicolumn{8}{|c|}{ Flow Experience } \\
\hline & \multicolumn{2}{|c|}{ MC } & \multicolumn{2}{|c|}{ DL } & \multicolumn{2}{|c|}{ TSD } & \multicolumn{2}{|c|}{ PP } \\
\hline & Pretest & Posttest & Pretest & Posttest & Pretest & Posttest & Pretest & Posttest \\
\hline & $M(S t d)$. & $M(S t d)$. & $M(S t d)$. & $M(S t d)$. & $M(S t d)$. & $M(S t d)$. & $M(S t d)$. & $M(S t d)$. \\
\hline \multirow{2}{*}{1} & 4.06 & 4.25 & 3.81 & 4.19 & 3.56 & 3.81 & 3.75 & 4.06 \\
\hline & $(0.32)$ & $(0.89)$ & $(0.42)$ & $(0.99)$ & $(0.31)$ & $(0.72)$ & $(0.79)$ & $(0.66)$ \\
\hline \multirow{2}{*}{2} & 3.38 & 3.19 & 3.63 & 3.13 & 3.19 & 3.06 & 3.00 & 3.13 \\
\hline & $(0.48)$ & $(0.63)$ & $(0.43)$ & $(0.75)$ & $(0.55)$ & $(0.52)$ & $(0.74)$ & $(0.72)$ \\
\hline \multirow{2}{*}{3} & 3.25 & 4.31 & 3.00 & 4.56 & 3.25 & 3.88 & 2.81 & 3.94 \\
\hline & $(0.74)$ & $(0.55)$ & $(1.02)$ & $(0.52)$ & $(0.41)$ & $(0.54)$ & $(0.75)$ & $(0.66)$ \\
\hline \multirow{2}{*}{4} & 3.25 & 3.63 & 3.44 & 3.38 & 3.19 & 3.38 & 3.00 & 3.25 \\
\hline & $(0.54)$ & $(0.43)$ & $(0.45)$ & $(0.75)$ & $(0.63)$ & $(0.68)$ & $(0.53)$ & $(0.42)$ \\
\hline \multirow{2}{*}{5} & 3.56 & 3.75 & 3.44 & 4.25 & 3.44 & 3.56 & 3.06 & 3.75 \\
\hline & $(0.59)$ & $(0.74)$ & $(0.75)$ & $(0.53)$ & $(0.55)$ & $(0.47)$ & $(0.55)$ & $(0.54)$ \\
\hline \multirow{2}{*}{6} & 3.56 & 4.19 & 3.69 & 3.81 & 3.38 & 3.38 & 2.94 & 3.63 \\
\hline & $(0.51)$ & $(0.55)$ & $(0.43)$ & $(0.66)$ & (0.49) & $(0.52)$ & $(0.66)$ & $(0.51)$ \\
\hline \multirow{2}{*}{7} & 3.75 & 3.44 & 3.69 & 3.44 & 3.56 & 3.56 & 3.56 & 3.81 \\
\hline & $(0.54)$ & $(0.80)$ & $(0.66)$ & (1.03) & $(0.43)$ & $(0.94)$ & $(0.38)$ & $(0.63)$ \\
\hline \multirow{2}{*}{8} & 4.00 & 4.75 & 3.94 & 4.94 & 3.50 & 4.31 & 3.56 & 4.00 \\
\hline & $(0.84)$ & $(0.53)$ & $(0.75)$ & $(0.52)$ & $(0.46)$ & $(0.63)$ & $(0.55)$ & $(0.61)$ \\
\hline \multirow{2}{*}{9} & 3.50 & 4.13 & 3.25 & 4.19 & 2.94 & 4.00 & 2.94 & 3.75 \\
\hline & $(0.53)$ & $(0.74)$ & $(0.65)$ & $(0.75)$ & $(0.48)$ & $(0.68)$ & $(0.52)$ & $(0.98)$ \\
\hline \multirow{2}{*}{10} & 3.63 & 4.06 & 3.50 & 3.94 & 3.19 & 3.75 & 3.13 & 3.19 \\
\hline & $(0.52)$ & $(0.66)$ & $(0.54)$ & $(0.65)$ & $(0.52)$ & $(0.88)$ & $(0.33)$ & $(0.93)$ \\
\hline \multirow{2}{*}{11} & 3.69 & 4.06 & 4.19 & 3.81 & 3.94 & 3.81 & 3.94 & 3.63 \\
\hline & $(0.69)$ & $(0.77)$ & $(0.39)$ & $(0.75)$ & $(0.52)$ & (0.59) & $(0.63)$ & $(0.44)$ \\
\hline \multirow{2}{*}{12} & 3.69 & 3.44 & 3.81 & 2.89 & 3.94 & 2.89 & 3.56 & 3.31 \\
\hline & $(0.90)$ & $(0.43)$ & $(0.83)$ & $(0.89)$ & $(0.66)$ & $(0.89)$ & $(0.66)$ & $(0.43)$ \\
\hline \multirow{2}{*}{ Total } & 3.60 & 3.93 & 3.61 & 3.96 & 3.39 & 3.67 & 3.27 & 3.61 \\
\hline & $(0.67)$ & $(0.88)$ & $(0.79)$ & $(0.84)$ & $(0.58)$ & $(0.83)$ & $(0.64)$ & $(0.81)$ \\
\hline
\end{tabular}

Note: $\mathrm{MC}=$ Mission challenge; $\mathrm{DL}=$ Dedication level; $\mathrm{TSD}=$ Time and space distortion; $\mathrm{PP}=$ Positive pleasure.

Table 6. Means test analysis for the creative self-efficacy in the pretest and posttest.

\begin{tabular}{cccccccc}
\hline Variables Sources & & $S S$ & $d f$ & $M S$ & $\boldsymbol{F}$ & $\eta^{2}$ & Sig. \\
\hline ECT $\times$ & Between groups & 3.66 & 1 & 3.66 & 7.88 & 0.077 & $0.006^{* *}$ \\
Pretest-Posttest & Within groups & 43.68 & 94 & 0.47 & & & \\
\hline ECP $\times$ & Between groups & 4.27 & 1 & 4.27 & 14.03 & 0.130 & $0.000^{* * *}$ \\
Pretest-Posttest & Within groups & 28.61 & 94 & 0.30 & & & \\
\hline PEFNF $\times$ & Between groups & 2.24 & 1 & 2.24 & 5.58 & 0.056 & $0.020^{*}$ \\
Pretest-Posttest & Within groups & 37.74 & 94 & 0.40 & & & \\
\hline Creative Self-Efficacy & Between groups & 3.11 & 1 & 3.11 & 11.83 & 0.112 & $0.001^{* *}$ \\
$\times$ Pretest-Posttest & Within groups & 24.69 & 94 & 0.26 & & & \\
\hline
\end{tabular}

${ }^{*} p<0.05,{ }^{* *} p<0.01,{ }^{* * *} p<0.001$. Note: ECT = Efficacy of creative thinking; ECP = Efficacy of creative production; PEFNF $=$ Persistence of efficacy in the face of negative feedback.

This study further used two-way analysis of variance (ANOVA) to analyze the effect of creativity tendency grouping and pretest-posttest on the creative self-efficacy total score (Table 7). The results revealed that for creativity tendency grouping variable, $F(1,95)=10.43$, and $p<0.01\left(p=0.002, \eta^{2}=0.102\right.$, $1-\beta=0.951)$. For the pretest-posttest variable, $F(1,95)=13.34$, and $p<0.001\left(p=0.000, \eta^{2}=0.127\right.$, $1-\beta=0.892)$. However, the interaction effect of creativity tendency grouping $\times$ pretest-posttest did not reach the significance level of $p<0.05(p=0.065)$. Thus, the two independent variables did not exert an interaction effect. 
Table 7. Two-way ANOVA for the effect of creativity tendency grouping and pretest versus posttest on the creative self-efficacy.

\begin{tabular}{ccccccc}
\hline Variables Sources & SS & $d f$ & MS & $\boldsymbol{F}$ & $\boldsymbol{\eta}^{\mathbf{2}}$ & $\mathbf{1 - \boldsymbol { \beta }}$ \\
\hline Creative Self-Efficacy (A) & 2.43 & 1 & 2.43 & $10.43^{* *}$ & 0.102 & 0.951 \\
Pretest-posttest (B) & 3.10 & 1 & 3.10 & $13.34^{* * *}$ & 0.127 & 0.892 \\
A $\times$ B & 0.83 & 1 & 0.83 & 3.55 & 0.037 & 0.762 \\
Error terms & 21.44 & 92 & 0.23 & & & \\
Total & 27.80 & 95 & & &
\end{tabular}

Calculating the estimated marginal means revealed that the pretest mean score of the lowcreativity tendency group was $2.93($ Std. $=0.43)$, whereas the posttest mean score was $3.48($ Std. $=0.56)$. The pretest mean score of the high-creativity tendency group was $3.44(S t d .=0.38)$, whereas the posttest mean score was $3.61(S t d .=0.54)$. One-way ANOVA was employed to determine whether pretest-posttest difference in the creative self-efficacy total score of the creativity tendency groups was significant. The results revealed that for the low-creativity tendency group, $F(1,46)=14.35$, and $p<0.001\left(p=0.000 ; M_{\text {posttest }}=3.47>M_{\text {pretest }}=2.93\right)$. For the high-creativity tendency group, $F(1,46)=1.68$, which was nonsignificant $(p=0.202)$. These findings indicated that integrating design thinking into the packaging design course improved the creative self-efficacy of the low-creativity tendency group.

\subsection{Flow Experience}

Similar to the tests for creative self-efficacy, a t test was first used in the posttest for gender to verify whether it affected flow experience. The test result was $t(1,52)=-0.016, p>0.05(p=0.494)$; therefore, gender did not affect flow experience. Secondly, the difference of means test was employed to evaluate the pretest-posttest differences in the flow experience variables (Table 8). The results revealed that for the MC dimension, $F(1,94)=6.37$, and $p<0.05\left(p=0.013, \eta^{2}=0.063 ; M_{\text {posttest }}=3.93>\right.$ $\left.M_{\text {pretest }}=3.60\right)$. For the DL dimension, $F(1,94)=6.54$, and $p<0.05\left(p=0.012, \eta^{2}=0.065 ; M_{\text {posttest }}=3.96\right.$ $\left.>M_{\text {pretest }}=3.61\right)$. For the TSD dimension, $F(1,94)=7.29$, and $p<0.01\left(p=0.008, \eta^{2}=0.072\right.$; $\left.M_{\text {posttest }}=3.67>M_{\text {pretest }}=3.38\right)$. For the PP dimension, $F(1,94)=7.72$, and $p<0.01(p=0.007$, $\left.\eta^{2}=0.076 ; M_{\text {posttest }}=3.62>M_{\text {pretest }}=3.27\right)$. Finally, for flow experience total score, $F(1,94)=7.65$, and $p<0.01\left(p=0.007, \eta^{2}=0.075 ; M_{\text {posttest }}=3.75>M_{\text {pretest }}=3.47\right)$. These results indicated that integrating design thinking into the packaging design course improved the students' flow experience.

Table 8. Means test analysis for the flow experience in the pretest and posttest.

\begin{tabular}{cccccccc}
\hline Variables Sources & & $S S$ & $d f$ & $M S$ & $F$ & $\eta^{2}$ & Sig. \\
\hline \multirow{2}{*}{ MC $\times$ Pretest-Posttest } & Between groups & 2.50 & 1 & 2.50 & 6.37 & 0.063 & $0.013^{*}$ \\
& Within groups & 36.96 & 94 & 0.39 & & & \\
\hline \multirow{2}{*}{ DL $\times$ Pretest-Posttest } & Between groups & 2.92 & 1 & 2.92 & 6.54 & 0.065 & $0.012^{*}$ \\
& Within groups & 41.99 & 94 & 0.45 & & & \\
\hline TSD $\times$ & Between groups & 1.97 & 1 & 1.97 & 7.29 & 0.072 & $0.008^{* *}$ \\
Pretest-Posttest & Within groups & 25.39 & 94 & .27 & & & \\
\hline \multirow{2}{*}{ PP $\times$ Pretest-Posttest } & Between groups & 2.92 & 1 & 2.92 & 7.72 & 0.076 & $0.007^{* *}$ \\
& Within groups & 24.69 & 94 & 0.26 & & & \\
\hline Flow Experience $\times$ & Between groups & 1.83 & 1 & 1.83 & 7.65 & 0.075 & $0.007^{* *}$ \\
Pretest-Posttest & Within groups & 22.47 & 94 & 0.24 & & & \\
\hline
\end{tabular}

${ }^{*} p<0.05,{ }^{* *} p<0.01$. Note: MC = Mission challenge; $\mathrm{DL}=$ Dedication level; TSD = Time and space distortion; $\mathrm{PP}=$ Positive pleasure. 
This study further used two-way ANOVA to examine the effect of creativity tendency grouping and time on flow experience (Table 9 ). For the creativity tendency grouping variable, $F(1,95)=9.46$, and $p<0.01\left(p=0.003, \eta^{2}=0.093,1-\beta=0.861\right)$. For the pretest versus posttest variable, $F(1,95)=22.37$, and $p<0.001\left(p=0.000, \eta^{2}=0.196,1-\beta=0.997\right)$. However, the interaction of creativity tendency grouping $\times$ pretest-posttest did not reach the significant level of $p<0.05(p=0.285)$. Thus, the two independent variables did not exert an interaction effect.

Table 9. Two-way ANOVA for the effect of creativity tendency grouping and pretest versus posttest on the flow experience total score.

\begin{tabular}{|c|c|c|c|c|c|c|}
\hline Variables Sources & SS & $d f$ & MS & $F$ & $\eta^{2}$ & $1-\beta$ \\
\hline Creative Self-Efficacy (A) & 1.98 & 1 & 1.98 & $9.46^{* *}$ & 0.093 & 0.861 \\
\hline Pretest-Posttest (B) & 4.69 & 1 & 4.69 & $22.37^{* * *}$ & 0.196 & 0.997 \\
\hline $\mathrm{A} \times \mathrm{B}$ & 0.24 & 1 & 0.24 & 1.16 & 0.013 & 0.686 \\
\hline Error terms & 19.29 & 92 & 0.21 & & & \\
\hline Total & 26.21 & 95 & & & & \\
\hline
\end{tabular}

Regarding the marginal mean, the pretest mean score of the low-creativity tendency group was $3.15(S t d .=0.39)$, and the posttest mean score was $3.69(S t d .=0.53)$. The pretest mean score of the high-creativity tendency group was $3.53(S t d .=0.50)$, and the posttest mean score was $3.88(S t d .=0.41)$. One-way ANOVA was employed to determine whether the flow experience pretest and posttest total scores of the two creativity tendency groups were significantly different. The results revealed that for the low-creativity tendency group, $F(1,46)=16.34$, and $p<0.001\left(p=0.000 ; M_{\text {posttest }}=3.69>M_{\text {pretest }}=3.15\right)$. For the high-creativity tendency group, $F(1,46)=6.90$, and $p<0.05\left(p=0.012 ; M_{\text {posttest }}=3.88>\right.$ $\left.M_{\text {pretest }}=3.54\right)$. These findings indicated that integrating design thinking into the packaging design course improved the flow experience of the students in both creativity tendency groups.

\section{Discussion}

\subsection{Influence of Design Thinking on Creative Self-Efficacy}

According to previous scholars, creative self-efficacy should include the three dimensions of creating ideas, solving problems, and improving others' ideas [43]. These dimensions are associated with those of package design. Packaging design is considered in the present study to be an extremely practical course. Its purpose is to guide students to identify problems with merchandise packaging and improve the packaging's look and functionality, with the target consumers as the starting point. In this study, a traditional lecture-based teaching method was used, and design thinking was also integrated into the course. The creative self-efficacy of the participants after each type of teaching was compared. Overall, integrating design thinking into the packaging design course improved the students' beliefs regarding their creative products, creative thinking strategies, and beliefs to contend against negative reviews. This study discovered that alternating the teaching method did not exert a significant influence on the students in the high-creativity tendency group but did improve the creative self-efficacy of the students in the low-creativity tendency group. Therefore, the creativity-conceiving process of design thinking can guide students with low-creativity tendency to believe more in their creative abilities. The existence and strengthening of such beliefs are particularly crucial to students learning packaging design, because an outstanding packaging designer must have sufficient confidence to propose innovative packaging designs and demonstrate the beliefs to contend against negative reviews.

Abbott [60] reported that creative self-efficacy is a state-like belief held by an individual regarding his or her ability to create novel, original, and adequate solutions according to the mission demands. In fact, improvement of creative self-efficacy is an extremely important creative factor for students learning packaging design. This is because merchandise packaging design is a group activity that 
requires creative ideas and solutions for existing problems with merchandise packaging. The traditional teaching method employed in packaging design courses (the lecture method, used in the pretest) involves expert lectures, case analysis, and group discussion. However, professional knowledge must be digested by individuals if they are to propose creative ideas during group discussion. This was not a problem for the high-creativity tendency group. Nevertheless, the students in the low-creativity tendency group feared that their creative ideas were not sufficiently mature, resulting in weak beliefs to persistence of efficacy in the face of negative feedback. Thus, they had less creative self-efficacy during the packaging design process. However, in the posttest, when design thinking had been integrated into the teaching method, the groups began by constructing an empathy map and visited markets in person to observe consumers. Accordingly, they identified problems regarding their package designs and created solutions to these problems. This human-centered thinking process enabled the students in the low-creativity tendency group to express their opinions more freely. Even if the final design products were not as expected, these students could build their creative confidence during the entire process of design thinking and creating. Thus, personal creative self-efficacy was improved.

After analyzing the aforementioned research results, Brown [22] maintained that design thinking effectively enables designers to think from the perspective of user demand, using the process of empathizing and defining problems to identify problems that users encounter. Subsequently, designers can come up with creative ideas to solve these problems. This human-centered design process entails the creative process of observing, engaging, watching, and listening [4]. This study posited that a human-centered design process can drive students to adopt the "point-of-view madlib" [61] method to determine "What type of people the users are?", "What the users' needs are?", and "Why the users have such needs?", allowing students to clearly define the goals and targets of the overall packaging design. During said design process, students of the low-creativity tendency group can think creatively and explore all design possibilities. They do not need to rely on their personal design talent to jointly create valuable packaging designs, allowing their creative self-efficacy to be inspired.

\subsection{Influence of Design Thinking on the Design Flow Experience}

Design thinking is an open creative thinking model in which group collaboration is employed as the starting point. It emphasizes the process of collective brainstorming and learning by doing, which are different from the traditional analytic thinking method [62]. More specifically, the analytical thinking method is based on understanding of professional knowledge. As in the pretest, students must acquire packaging design knowledge from the teacher and the content of a case analysis before being able to express their own opinions during group discussion. Otherwise, an individual's motivation to participate in the group discussion and execute the subsequent merchandise packaging design is influenced. However, the design thinking teaching method employed in the posttest is a creative thinking learning method and a process for devising something out of nothing or a creative thinking process in which order is established from chaos. The group members set aside their basic knowledge of packaging design and made an effort to understand customers' real needs through actual observation and interviews in markets. Finally, the design selling points were created collectively though brainstorming. This process was not a comparison of professional knowledge but identification of where problems are. Finally, the methods or strategies for solving the problems were proposed. The integration of design thinking into the packaging design course help the students feel more comfortable facing challenges. In addition, the students' willingness to dedicate themselves to the mission was increased, and more creative pleasure was obtained. This describes the flow experience during the packaging design. In fact, flow experience is closely related to internal motivation. The generation of internal motivation is the source of personal creative power [35]. In this study, design thinking was considered to trigger generation of greater internal motivation for students. Students can acquire a favorable design flow experience by completing creative missions. 
The relationship between internal motivation and flow experience was further discussed. Although personal mission motivation is a stable personality trait [63], scenario motivation changes according to the field and external scenario [64,65]. Csikszentmihalyi [49] considered flow experience to be the feeling and process of an individual expressing internal motivation. It is also a state in which an individual is completely dedicated to their current activity. The discourses of the aforementioned scholars were connected to this empirical teaching study. The present study discovered that design thinking can improve the design flow experience for students with low-creativity tendency and be beneficial to students with high-creativity tendency. Design thinking thus enables individuals of differing creativity tendencies to achieve the same creative feelings and be similarly immersed in the process of packaging design. This innovative design education method can trigger students' scenario motivation and increase students' willingness to dedicate themselves to creative thinking. In fact, the nature of packaging design teaching is the transmission of design thinking and the process of teaching design methods. The real purpose of the course is not to cultivate designers but to guide students' expressiveness and ability to solve practical problems. Thus, innovative packaging design ideas can be proposed. However, previous packaging design education was mostly concerned with evaluating results, causing students with lower-creativity tendency to be more afraid of expressing their opinions during group discussion. They fear that immature creative ideas cannot benefit the team, and learning passion is consumed little by little. In summary, this study used teaching experiments to verify that integrating design thinking into a packaging design course had a positive influence on students' creative flow experience.

\subsection{Benefits of Design Thinking for the Packaging Design Course}

To respond to an increasingly complex society, a packaging designer must learn to think from the perspective of consumer needs through the five Ws of design thinking, namely what is the merchandise (What), who is the selling target (Who), when is the selling time (When), where is the merchandise sold (Where), and why is such design needed (Why). However, packaging design courses lack the level of consuming thinking. Students can design beautiful merchandise packaging, but their thinking regarding merchandise positioning and target consumers is not accurate enough. Thus, they often design merchandise packaging that does not meet consumers' needs. Therefore, this teaching experiment attempted to introduce design thinking into a packaging design course. The students were guided to escape the parochialism of design by entering the consumers' perspective through actual observation in markets and customer interviews. They did not design only for the design but examined the necessity and style of package design from the perspective of market segmentation and consumer needs. Thus, the learning goal of adding value to packaging design was achieved. According to the discourse of Stanford University d. school, the learning goal of design thinking is to enable every student to become an innovator [26]. This study was based on the double diamond design process of Stanford d. school [28]. Students were trained to escape the traditional analytical thinking and utilize creative methods in design thinking during packaging design. From "What" and "Who" to "Why" and "How," the packaging design course became more interesting, stimulated students' creative self-efficacy, and improved the design flow experience. The teaching implementation methods are explained as follows (Figure 2):

1. Human-centered perspective: From the perspective of market segmentation, consumers' real problems related to packaging design when purchasing merchandise were observed during the actual purchasing process in markets. Creative ideas that could solve the problems were proposed.

2. Empathy map: One specific consumer was selected from the consumer population, and his emotions and thoughts when buying merchandise were discovered. The students had to understand his viewpoint and feelings and stand in his shoes to think and deal with the problems he may have encountered. 
3. Mindful of the opinion process: When one group member was providing creative ideas for packaging design, other members only listened and did not give reviews. They could also extend others' ideas. Numerous creative ideas were generated throughout the brainstorming process.

4. Rapid prototyping: The package prototypes were rapidly manufactured using storyboards, computer graphics, or cardboard to verify the ideas. In addition, the problems were corrected repeatedly to ensure the ideas met consumers' needs.

5. Radical collaboration: Every group member had to find their position in the team. The members had to respect the ideas proposed by others while being willing to share their own experiences and ideas. Criticism was replaced by acceptance in an effort to collectively find solutions to the problems.

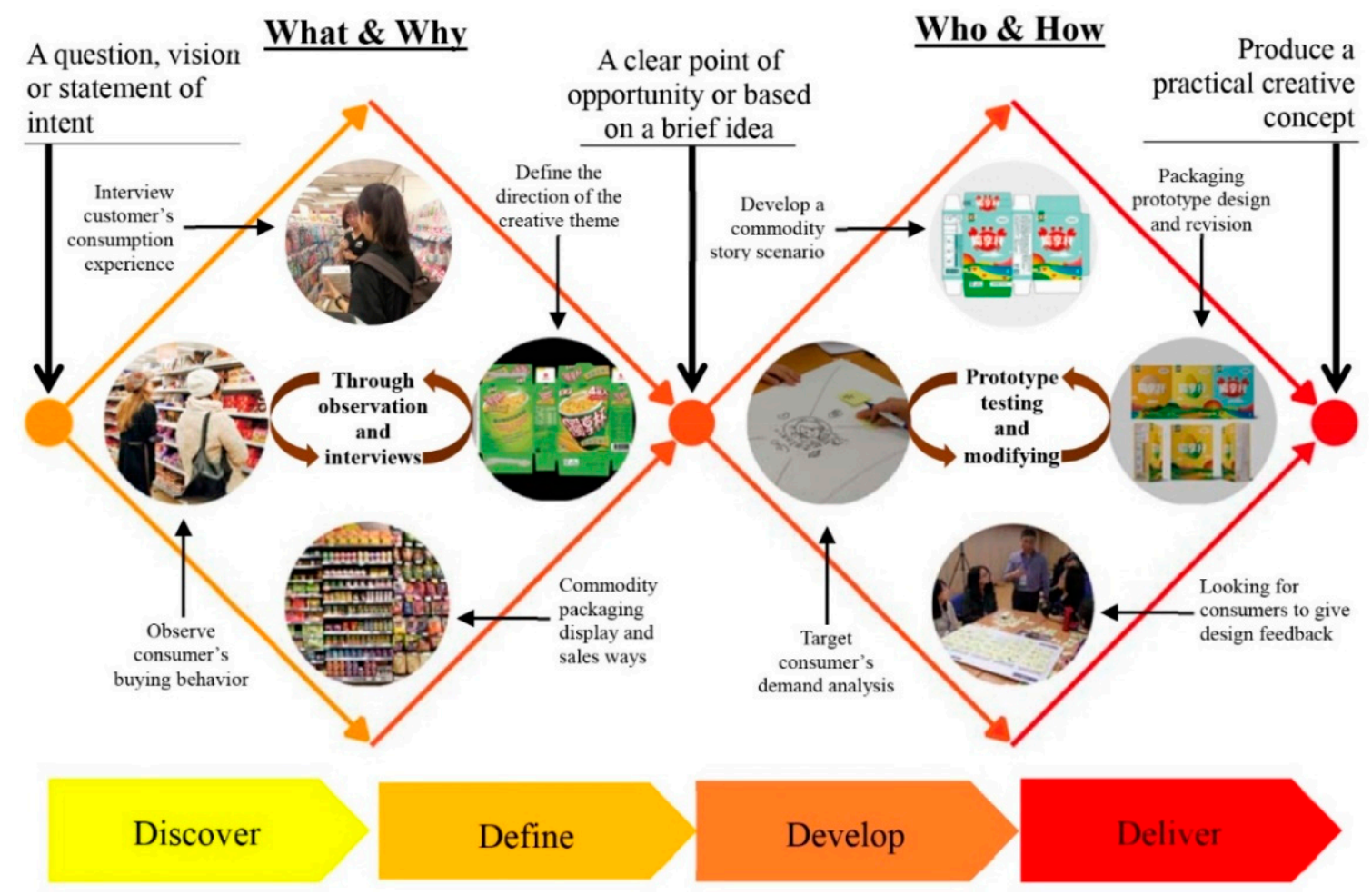

Figure 2. Teaching implementation methods of introducing the double diamond design process into the packaging design course.

\section{Conclusions and Recommendations}

This study used a sample of 54 students and grouped them into 12 groups through random designation. Two packaging design teaching methods were employed, and pretest and posttest teaching experiments were conducted. Finally, this study verified that the innovative teaching method of design thinking can improve students' creative self-efficacy and flow experience and is particularly beneficial for students with low-creativity tendency. For the teaching experiments performed in this study, the teachers demanded that the students adopt the group collaborative learning method to complete the packaging design assignments during both the pretest (which involved the use of the lecture teaching method) and the posttest (which involved the use of the design thinking-based teaching method). The group collaborative learning design method enabled the students to express their ideas, interact with others, and learn from each other, facilitating the following results: the teachers encouraging students to actively learn, group members having a positive relationship where they trusted and relied on each other; group members having common tasks to be completed; and teachers' changing their role to that of facilitators [66]. The success of group collaborative learning generally relies on the efforts made by each group member. Dillenbourg [67] noted that collaborative 
learning carried out in real-life situations enables group members to interact more smoothly and naturally than that in classroom settings. However, the teaching experiment conducted in this study did not verify whether this was the reason the students' packaging design creativity and immersive experience was enhanced during the posttest (which involved the use of the design thinking-based teaching method), and further research is required to explore whether this was true.

In addition, this study also makes the following research recommendations. First, the sample in this teaching experiment was only a class of 54 students. The sample was thus small, and if the same teaching experiment could be conducted with more classes in the future, the results of this study could be generalized. Second, the medians of the total scores for the Williams Creativity Tendency scale were used in this study as the cutoff for grouping students into high and low creativity tendency groups. The mean total scores of the two creativity tendency groups $\left(M_{\text {high-creativity tendency }}=127.54\right.$; $M_{\text {low-creativity tendency }}=108.58$ ) conformed to the category characteristics of the Williams Creativity Tendency scale. Namely, a test score of 120-134 indicates high creativity, whereas 90-119 indicates moderate creativity. Most researchers would group participants according to the median. However, this study recommends that the quartile method be employed for similar teaching research in the future. Accordingly, the groups with the largest and smallest scores can be selected for the experiments, further distinguishing the creativity tendency levels of the high- and low-tendency groups.

Third, the goal of design thinking is to stimulate students' creativity potential. Their ability to solve problems is trained during the process, and evaluation of students' creative output is not emphasized. Therefore, this empirical teaching research focused on whether design thinking improves the creative self-efficacy and flow experience. The learning outcomes of the pretest and posttest were not examined statistically. Creative self-efficacy and flow experience are both internal feelings of individuals participating in creative activities. From this perspective, the results of this study can only demonstrate whether integrating design thinking into the packaging design course was beneficial to the students' creative self-efficacy and flow experience. Whether design thinking can improve the results of packaging design requires further empirical research for verification. However, due to the nature of creativity, a display of creativity should include the presentation of learning results. Consequently, this study recommends that for similar research in the future, students' creative results should be evaluated by experts and scholars. Thus, the learning outcomes of the innovative teaching method can be further understood. Finally, the flow experience measured in this study was intimately related to the students' internal motivation. However, according to the discourses of previous scholars, the factors influencing creativity performance include external motivations as well as internal motivations. These external motivations are the influence factors of the external environment [64]. In subsequent research, expected evaluation [51] can be used as a mediator variable. Whether design thinking still improves creative self-efficacy and flow experience when students are informed that their work will be evaluated must be discussed.

Author Contributions: Conceptualization, C.-M.Y.; methodology, C.-M.Y. and T.-F.H.; formal analysis, C.-M.Y.; writing-original draft preparation, C.-M.Y. and T.-F.H.; writing-review and editing, C.-M.Y. and T.-F.H. All authors have read and agreed to the published version of the manuscript.

Funding: This research was funded by Taiwan's MOE Teaching Practice Research Program grant number PHA1080016, and the APC was funded by Ming Chi University of Technology.

Acknowledgments: The authors thank all students who participated in this teaching experiment.

Conflicts of Interest: The authors declare no conflict of interest. 


\section{Appendix A}

Table A1. Course Plans for the Pretest and Posttest.

\begin{tabular}{|c|c|c|}
\hline Course Information & & Description of Content \\
\hline Teaching goals & $\begin{array}{l}\text { To cultivate students' thinking } \mathrm{f}_{\mathrm{i}} \\
\text { structures, merchandise marketi } \\
\text { attain visual esthetic appreciatio }\end{array}$ & $\begin{array}{l}\text { e perspective of merchandise packaging, brand image, and marketing. The course addressed packaging's spatial } \\
\text { sitions, and graphic design. Students were trained to improve the creativity of the structure of merchandise packaging, } \\
\text { ctice design thinking, and solve design problems through rational analysis. }\end{array}$ \\
\hline Course content & $\begin{array}{l}\text { Packaging materials and product } \\
\text { merchandise packaging, mercha }\end{array}$ & $\begin{array}{l}\text {, packaging design and business marketing, design forms of packaging container structures, visual design techniques for } \\
\text { packaging demand definitions, creative thinking for packaging design, and packaging structural design tests. }\end{array}$ \\
\hline \multirow{10}{*}{ Teaching activities } & \multirow{5}{*}{$\begin{array}{l}\text { Didactic teaching } \\
\quad \text { (Pretest) }\end{array}$} & $\begin{array}{l}\text { The teacher selected } 12 \text { products in advance: tea leave bag, dried fruit, cookie, oatmeal, corn chip, ice cream, milk tea } \\
\text { bag, instant coffee, bouillon cube, chocolate, candy, and insecticide. The teams randomly selected a product and } \\
\text { completed the course mission for packaging design. The main teaching methods in the pretest course were as follows: }\end{array}$ \\
\hline & & $\begin{array}{l}\text { 1. Class lectures: The teacher lectured on the types and functions of packaging design, packaging materials and } \\
\text { product forms, visual design techniques for packaging, and related professional knowledge and } \\
\text { practice techniques. }\end{array}$ \\
\hline & & \\
\hline & & $\begin{array}{l}\text { 3. Group discussion: The brand characteristics, consumer population, product traits, product display, and problems } \\
\text { with the current merchandise packing were analyzed. Innovative packaging design was then performed. }\end{array}$ \\
\hline & & $\begin{array}{l}\text { 4. Class practice: The packaging design ideas and improvements of actual products were conducted in group } \\
\text { collaboration. The students practiced solving problems. }\end{array}$ \\
\hline & \multirow{5}{*}{$\begin{array}{l}\text { Design thinking teaching } \\
\text { (Posttest) }\end{array}$} & $\begin{array}{l}\text { The teacher selected } 12 \text { products in advance: milk brand jelly, pineapple cake, cookie, salt shaker, chocolate, bouillon } \\
\text { cube, alcohol, corn chip, lozenge, shampoo, tea leave bag, and light bulb. the teams randomly selected a product and } \\
\text { completed the course mission for packaging design. The main teaching methods of the posttest were as follows: }\end{array}$ \\
\hline & & $\begin{array}{l}\text { 1. Empathy map: The students went to actual markets to observe how merchandise was displayed and understand } \\
\text { the problems of consumers and merchandise packaging design. }\end{array}$ \\
\hline & & $\begin{array}{l}\text { 2. Need definition: The students thought about the relationship between merchandise packaging and specific users } \\
\text { and redefined the definite needs of consumers. }\end{array}$ \\
\hline & & Conceiving ideas: Group members brainstormed together, shared solutions with each other, and conceived ideas. \\
\hline & & $\begin{array}{l}\text { 4. Manufacturing prototypes: The students designed a specific character, collectively told a story, and manufactured } \\
\text { prototypes of their merchandise packaging. }\end{array}$ \\
\hline
\end{tabular}


Table A2. Merchandise Packaging Design Completed by Students in the Pretest and Posttest.

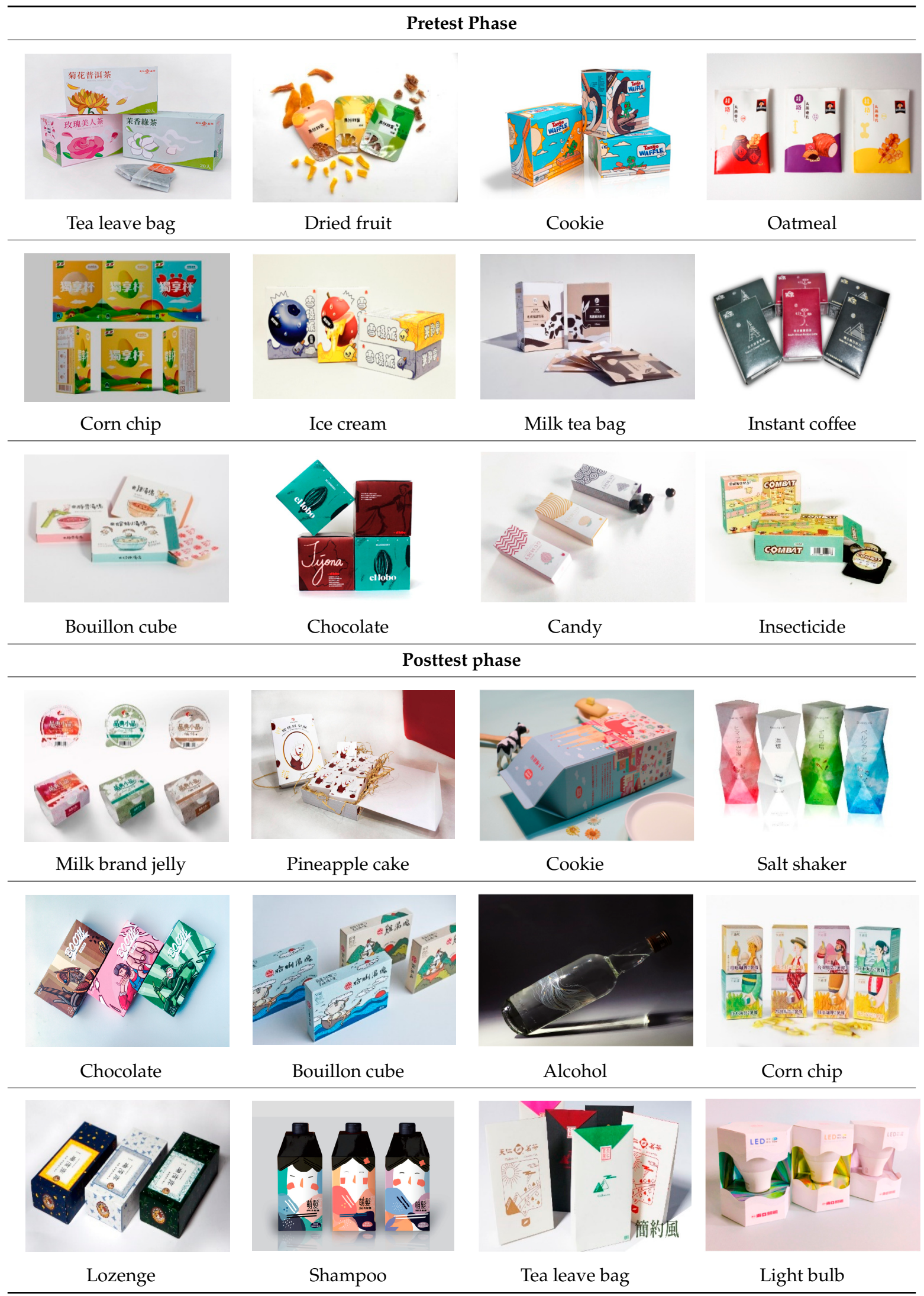




\section{References}

1. Behaeghel, J. Brand Packaging: The Permanent Medium; Architecture Design and Technology Press: London, UK, 1991.

2. Rettie, R.; Brewer, C. The verbal and visual components of package design. J. Prod. Brand Manag. 2000, 9, 56-70. [CrossRef]

3. Vyas, H.V. Packaging Design Elements and Users Perception: A Context in Fashion Branding and Communication. J. Appl. Packag. Res. 2015, 7, 95-107. [CrossRef]

4. Yang, C.-M. Applying Design Thinking as a Method for Teaching Packaging Design. J. Educ. Learn. 2018, 7, 52. [CrossRef]

5. DuPuis, S.; Silva, J. Package Design Workbook: The Art and Science of Successful Packaging; Rockport Publishers: New York, NY, USA, 2008; pp. 65-75.

6. Orth, U.R.; Malkewitz, K. Holistic package design and consumer brand impressions. J. Mark. 2008, 72, 64-81. [CrossRef]

7. Wang, J. Discussion on the reform of packaging design training course in higher vocational colleges. J. Shandong Inst. Commer. Tech. 2016, 1, 33-37.

8. Hmelo-Silver, C.E. Problem-Based Learning: What and How Do Students Learn? Educ. Psychol. Rev. 2004, 16, 235-266. [CrossRef]

9. Dunne, D.; Martin, R. Design Thinking and How It Will Change Management Education: An Interview and Discussion. Acad. Manag. Learn. Educ. 2006, 5, 512-523. [CrossRef]

10. Melles, G.; Howard, Z.; Thompson-Whiteside, S. Teaching Design Thinking: Expanding Horizons in Design Education. Procedia Soc. Behav. Sci. 2012, 31, 162-166. [CrossRef]

11. Razzouk, R.; Shute, V. What Is Design Thinking and Why Is It Important? Rev. Educ. Res. 2012, 82, 330-348. [CrossRef]

12. Lugmayr, A. Applying design thinking as a method for teaching in media education. In Proceedings of the 15th International Academic MindTrek Conference: Envisioning Future Media Environment, Tampere, Finland, 28 September 2011; Association for Computing Machinery: New York, NY, USA, 2011; pp. 332-334.

13. Chan, S.; Yuen, M. Personal and environmental factors affecting teachers' creativity-fostering practices in Hong Kong. Think. Ski. Creat. 2014, 12, 69-77. [CrossRef]

14. Chang, C.-P.; Chuang, H.-W.; Bennington, L. Organizational climate for innovation and creative teaching in urban and rural schools. Qual. Quant. 2010, 45, 935-951. [CrossRef]

15. Limon, Y.; Kahle, L.R.; Orth, U.R. Package Design as a Communications Vehicle in Cross-Cultural Values Shopping. J. Int. Mark. 2009, 17, 30-57. [CrossRef]

16. Wells, L.; Farley, H.; Armstrong, G. The importance of packaging design for own-label food brands. Int. J. Retail. Distrib. Manag. 2007, 35, 677-690. [CrossRef]

17. Schoormans, J.P.; Robben, H.S. The effect of new package design on product attention, categorization and evaluation. J. Econ. Psychol. 1997, 18, 271-287. [CrossRef]

18. Ampuero, O.; Vila, N.; Vila-López, N. Consumer perceptions of product packaging. J. Consum. Mark. 2006, 23, 100-112. [CrossRef]

19. Rundh, B. Packaging design: Creating competitive advantage with product packaging. Br. Food J. 2009, 111, 988-1002. [CrossRef]

20. Calver, G. What is Packaging Design? Rotovision: New York, NY, USA, 2004.

21. Abdallah, N. Packaging design course teaching improvement: A case study in the faculty of applied arts, Egypt. Indian J. Sci. Technol. 2010, 3, 1108-1112. [CrossRef]

22. Brown, T. Design thinking. Harv. Bus. Rev. 2008, 86, 84-92.

23. Lugmayr, A.; Stockleben, B.; Zou, Y.; Anzenhofer, S.; Jalonen, M. Applying "Design Thinking" in the context of media management education. Multimed. Tools Appl. 2013, 71, 119-157. [CrossRef]

24. Johansson-Sköldberg, U.; Woodilla, J.; Çetinkaya, M. Design Thinking: Past, Present and Possible Futures. Creat. Innov. Manag. 2013, 22, 121-146. [CrossRef]

25. Scheer, A.; Noweski, C.; Meinel, C. Transforming constructivist learning into action: Design thinking in education. Int. J. Technol. Des. Educ. 2012, 17, 8-19. 
26. Rauth, I.; Köppen, E.; Jobst, B.; Meinel, C. Design Thinking: An Educational Model towards Creative Confidence. In DS 66-2, Proceedings of the 1st International Conference on Design Creativity (ICDC), Kobe, Japan, 29 November-1 December 2010; The Design Society: Glasgow, UK, 2010.

27. Lindberg, T.; Wagner, R.; Meinel, C. Design Thinking: A Fruitful Concept for IT Development? In Design Thinking; Springer Science and Business Media LLC: Berlin/Heidelberg, Germany, 2010; pp. 3-18.

28. Tschimmel, K. Design Thinking as an effective Toolkit for Innovation. In Proceedings of the XXIII ISPIM Conference: Action for Innovation: Innovating from Experience, Barcelona, Spain, Barcelona, Spain, 17-20 June 2012.

29. Kampylis, P.; Valtanen, J. Redefining Creativity-Analyzing Definitions, Collocations, and Consequences. J. Creat. Behav. 2010, 44, 191-214. [CrossRef]

30. Weisberg, R.W. On the Usefulness of "Value" in the Definition of Creativity. Creat. Res. J. 2015, 27, 111-124. [CrossRef]

31. Dubina, I.N. Managing creativity: Theoretical approaches to employees' creativity development and regulation. Int. J. Manag. Concepts Philos. 2005, 1, 334. [CrossRef]

32. Pelaprat, E.; Cole, M. "Minding the Gap": Imagination, Creativity and Human Cognition. Integr. Physiol. Behav. Sci. 2011, 45, 397-418. [CrossRef]

33. Runco, M.A.; Sakamoto, S.O. Experimental Studies of Creativity. In Handbook of Creativity; Sternberg, R.J., Ed.; Cambridge University Press: Cambridge, UK, 1999; pp. 62-92.

34. Niu, W. Individual and Environmental Influences on Chinese Student Creativity. J. Creat. Behav. 2007, 41, 151-175. [CrossRef]

35. Sternberg, R.J.; Lubart, T.I. The Concept of Creativity: Prospects and Paradigms. In Handbook of Creativity; Sternberg, R.J., Ed.; Cambridge University Press: Cambridge, UK, 1999; pp. 3-15.

36. Williams, F.E. Assessing creativity pupti-teacher behavior related to a cognitive-affective teaching model. J. Res. Dev. Educ. 1971, 4, 14-22.

37. Williams, F.E. Creativity Assessment Packet (CAP); D.O.K: Buffalo, NY, USA, 1980.

38. Cropley, A.J. Creativity in Education E Learning: A Guide for Teachers and Educators; Routledge: New York, NY, USA, 2010.

39. Puccio, G.; Grivas, C. Examining the Relationship between Personality Traits and Creativity Styles. Creat. Innov. Manag. 2009, 18, 247-255. [CrossRef]

40. Maddux, W.; Galinsky, A.D. Cultural borders and mental barriers: The relationship between living abroad and creativity. J. Pers. Soc. Psychol. 2009, 96, 1047-1061. [CrossRef]

41. Ivcevic, Z.; Mayer, J.D. Creative Types and Personality. Imagin. Cogn. Pers. 2006, 26, 65-86. [CrossRef]

42. Qian, M.; Plucker, J.A.; Shen, J. A Model of Chinese Adolescents' Creative Personality. Creat. Res. J. 2010, 22, 62-67. [CrossRef]

43. Tierney, P.; Farmer, S.M. Creative self-efficacy: Its potential antecedents and relationship to creative performance. Acad. Manag. J. 2002, 45, 1137-1148.

44. Linnenbrink, E.A.; Pintrich, P.R. Motivation as an enabler for academic success. Sch. Psych. Rev. 2002, 31, 313-327.

45. Gong, Y.; Huang, J.-C.; Farh, J.-L. Employee Learning Orientation, Transformational Leadership, and Employee Creativity: The Mediating Role of Employee Creative Self-Efficacy. Acad. Manag. J. 2009, 52, 765-778. [CrossRef]

46. Huang, L.; Krasikova, D.V.; Liu, D. I can do it, so can you: The role of leader creative self-efficacy in facilitating follower creativity. Organ. Behav. Hum. Decis. Process. 2016, 132, 49-62. [CrossRef]

47. Jaussi, K.S.; Randel, A.; Dionne, S.D. I Am, I Think I Can, and I Do: The Role of Personal Identity, Self-Efficacy, and Cross-Application of Experiences in Creativity at Work. Creat. Res. J. 2007, 19, 247-258. [CrossRef]

48. Mathisen, G.E.; Brønnick, K. Creative self-efficacy: An intervention study. Int. J. Educ. Res. 2009, 48, $21-29$. [CrossRef]

49. Csikszentmihalyi, M. The flow experience and its significance for human psychology. In Optimal Experience: Psychological Studies of Flow in Consciousness; Csikszentmihalyi, M., Csikszentmihalyi, I.S., Eds.; Cambridge University Press: Cambridge, UK, 1988; pp. 15-35.

50. Csikszentmihalyi, M. Implications of a Systems Perspective for the Study of Creativity. In Handbook of Creativity; Stenberg, R.J., Ed.; Cambridge University Press: Cambridge, UK, 1999; pp. 313-336. 
51. Wang, J.; Liu, R.-D.; Dong, H.-Z. How expected evaluation influences creativity: Regulatory focus as moderator. Motiv. Emot. 2016, 41, 147-157. [CrossRef]

52. Prabhu, V.; Sutton, C.; Sauser, W. Creativity and Certain Personality Traits: Understanding the Mediating Effect of Intrinsic Motivation. Creat. Res. J. 2008, 20, 53-66. [CrossRef]

53. Xie, Y.; DeVellis, R.F. Scale Development: Theory and Applications, 3rd ed.; SAGE Publications: Thousand Oaks, CA, USA, 2012; Volume 26, pp. 63-82.

54. Beghetto, R. Creative Self-Efficacy: Correlates in Middle and Secondary Students. Creat. Res. J. 2006, 18, 447-457. [CrossRef]

55. Hung, S.-P. Validating the creative self-efficacy student scale with a Taiwanese sample: An item response theory-based investigation. Think. Skills Creat. 2018, 27, 190-203. [CrossRef]

56. Buil, I.; Catalán, S.; Martinez, E. Exploring students' flow experiences in business simulation games. J. Comput. Assist. Learn. 2018, 34, 183-192. [CrossRef]

57. Walker, C.J. Experiencing flow: Is doing it together better than doing it alone? J. Posit. Psychol. 2010, 5, 3-11. [CrossRef]

58. Yoshida, K.; Asakawa, K.; Yamauchi, T.; Sakuraba, S.; Sawamura, D.; Murakami, Y.; Sakai, S. The Flow State Scale for Occupational Tasks: Development, Reliability, and Validity. Hong Kong J. Occup. Ther. 2013, 23, 54-61. [CrossRef]

59. Magyaródi, T.; Nagy, H.; Soltész, P.; Mózes, T.; Oláh, A. Psychometric properties of a newly established flow state questionnaire. J. Happiness Well Being 2013, 1, 85-96.

60. Abbott, D.H. Constructing a Creative Self-Efficacy Inventory: A Mixed Methods Inquiry. Ph.D. Thesis, University of Nebraska-Lincoln, Lincoln, NE, USA, May 2010.

61. Von Thienen, J.; Meinel, C.; Nicolai, C. Implications of a systems perspective for the study of creativity. In Design Thinking Research; Plattner, H., Meinel, C., Leifer, L., Eds.; Springer: Cham, Switzerland, 2014; pp. 97-102.

62. Brown, T.; Wyatt, J. Design Thinking for Social Innovation. Stanford Soc. Innov. Rev. 2010, 12, $29-43$. [CrossRef]

63. Eysenck, H.J. Personality and the experimental study of education. Eur. J. Pers. 1996, 10, 427-439. [CrossRef]

64. Amabile, T.M. Motivational synergy: Toward new conceptualizations of intrinsic and extrinsic motivation in the workplace. Hum. Resour. Manag. Rev. 1993, 3, 185-201. [CrossRef]

65. Amabile, T.M. A model of creativity and innovation in organizations. J. Organ. Behav. 1988, 10, $123-167$.

66. Strijbos, J.; Martens, R.; Jochems, W. Designing for interaction: Six steps to designing computer-supported group-based learning. Comput. Educ. 2004, 42, 403-424. [CrossRef]

67. Dillenbourg, P. (Ed.) What do you mean by collaborative learning? In Collaborative Learning: Cognitive and Computational Approaches; Elsevier: Oxford, UK, 1999; pp. 1-19. 